\title{
Understanding the neurotropic characteristics of SARS-CoV-2: from neurological manifestations of COVID-19 to potential neurotropic mechanisms
}

\author{
Zhiqiang Zhou ${ }^{1} \cdot$ Huicong Kang ${ }^{2} \cdot$ Shiyong $\mathrm{Li}^{1} \cdot \mathrm{Xu} \mathrm{Zhao}^{3}$ (I)
}

Received: 15 April 2020 / Revised: 14 May 2020 / Accepted: 16 May 2020 / Published online: 26 May 2020

(c) Springer-Verlag GmbH Germany, part of Springer Nature 2020

\begin{abstract}
Coronavirus disease 2019 (COVID-19), a disease caused by the novel betacoronavirus (SARS-CoV-2), has become a global pandemic threat. The potential involvement of COVID-19 in central nervous system (CNS) has attracted considerable attention due to neurological manifestations presented throughout the disease process. In addition, SARS-CoV-2 is structurally similar to SARS-CoV, and both bind to the angiotensin-converting enzyme 2 (ACE2) receptor to enter human cells. Thus, cells expressing ACE2, such as neurons and glial cells may act as targets and are thus vulnerable to SARS-CoV-2 infection. Here, we have reviewed the neurological characteristics of COVID-19 and summarized possible mechanisms of SARSCoV-2 invasion of the CNS. COVID-19 patients have presented with a number of different neurological symptoms such as headache, dizziness, hyposmia, and hypogeusia during the course of illness. It has also been reported recently that some cases of COVID-19 have presented with concurrent acute cerebrovascular disease (acute ischemic stroke, cerebral venous sinus thrombosis, cerebral hemorrhage, subarachnoid hemorrhage), meningitis/encephalitis, acute necrotizing hemorrhagic encephalopathy, and acute Guillain-Barré syndrome. Furthermore, SARS-CoV-2 RNA detected in a cerebrospinal fluid specimen of a patient with COVID-19 have provided direct evidence to support the theory of neurotropic involvement of SARS-CoV-2. However, the underlying neurotropic mechanisms of SARS-CoV-2 are yet to be established. SARS-CoV-2 may affect CNS through two direct mechanisms (hematogenous dissemination or neuronal retrograde dissemination) or via indirect routes. The underlying mechanisms require further elucidation in the future.
\end{abstract}

Keywords COVID-19 $\cdot$ SARS-CoV-2 $\cdot$ Neurotropic $\cdot$ ACE2

Xu Zhao

zhaoxu96@163.com

1 Department of Anesthesiology and Pain Medicine, Tongji Hospital, Tongji Medical College, Huazhong University of Science and Technology, Wuhan, People's Republic of China

2 Department of Neurology, Tongji Hospital, Tongji Medical College, Huazhong University of Science and Technology, Wuhan, People's Republic of China

3 Department of Radiology, Tongji Hospital, Tongji Medical College, Huazhong University of Science and Technology, 1095 Jiefang Avenue, Wuhan, Hubei, People's Republic of China

\section{Introduction}

Coronavirus disease 2019 (COVID-19), a disease caused by the novel betacoronavirus (SARS-CoV-2), has become a pandemic threat leading to more than $4,170,000$ confirmed cases and 287,399 deaths globally, as declared by the World Health Organization (WHO) on May 13th, 2020. Although the most common symptoms of COVID-19 are fever and cough, a number of patients have experienced neurological manifestations such as headache, dizziness, hypogeusia and hyposmia during the course of the illness [1-4]. In addition, patients requiring intensive care unit (ICU) care were more likely to have underlying comorbidities such as cerebrovascular disease (CVD), hypertension, cardiovascular disease, diabetes, or cancer than patients who did not require ICU care [3]. Furthermore, it has been found that the receptor-binding domain of SARS-CoV-2 is similar to that of SARS-CoV, the virus that is responsible 
for the pandemic infectious disease-severe acute respiratory syndrome (SARS)—-happened in 2002 and 2003 [5]. SARS-CoV-2 binds to the angiotensin-converting enzyme 2 (ACE2) receptor to access human cells, as does SARS-CoV [5]. Therefore, cells expressing ACE2 may act as targets and thus are vulnerable to SARS-CoV-2 infection. Specifically, it has also been reported that glial cells and neurons, in addition to endothelial and arterial smooth muscle cells in the brain express ACE2 receptors, which renders them potential targets of SARS-CoV-2 [6-8]. Such evidence indicates potential neurotropic involvement of SARS-CoV-2 [8-10]. It is therefore of great importance to investigate its neurotropic effects and to understand the underlying mechanisms. Thus, we have reviewed the neurological characteristics of COVID-19 and summarized possible mechanisms of SARSCoV-2 involvement in the central nervous system (CNS).

\section{Neurological manifestations of COVID-19}

Increasing evidence indicates that coronaviruses may invade the CNS, causing neurological disorders. Headache has been the most common neurological manifestation reported by COVID-19 patients [1,2]. A systematic review of 554 COVID-19 patients concluded that the mean prevalence of headache was $8 \%$ (95\% CI 5.7-10.2\%) [11]. Apart from headache, dizziness is also a common neurological manifestation of COVID-19, with a reported prevalence of between 7 and $9.4 \%$ [3, 12]. Of 138 hospitalized patients, those who required ICU care $(n=36)$ were more likely to report dizziness than those who did not $(n=102)$ (ICU 8/36 [22.2\%] vs non-ICU 5/102 [4.9\%], $P=0.007)$ [3]. Confusion and headache were the fifth (9/99 [9\%]) and sixth (8/99 [8\%]) most common symptoms of the 99 COVID-19 patients at admission, respectively [13]. Furthermore, it has recently been reported that a number of cases of COVID-19 have had concurrent severe neurological symptoms, such as acute CVD (acute ischemic stroke, cerebral venous sinus thrombosis, cerebral hemorrhage, subarachnoid hemorrhage), meningitis/encephalitis, acute necrotizing hemorrhagic encephalopathy, and acute Guillain-Barré syndrome [14-19].

It is worth noting that the prevalence of neurological manifestations was higher in a report by Ling et al. who paid more attention to the neurological manifestations of COVID19 than the aforementioned studies. Of the 214 COVID-19 patients in that report, 78 (36.4\%) patients had neurological manifestations. Compared with non-severe patients, severe patients were more likely to have neurological symptoms (40 [45.5\%] vs 38 [30.2\%], $P<0.05)$, such as acute CVD (5 [5.7\%] vs $1[0.8 \%], P<0.05)$, impaired consciousness (13 [14.8\%] vs $3[2.4 \%], P<0.001)$ or skeletal muscle injury (17 [19.3\%] vs 6 [4.8\%], $P<0.001)$. The most common neurological manifestation was dizziness (36 [16.8\%]), followed by headache (28 [13.1\%]), impaired consciousness (16 [7.5\%]), acute CVD (6 [2.8]), ataxia (1 [0.5\%]) and seizure (1 [0.5\%]). In addition, symptoms involving the cranial nerves, such as hypogeusia, hyposmia, hypopsia, and neuralgia have also been reported in $19(8.9 \%)$ patients [4]. The reason for the difference in incidence of different neurological manifestations between the various reports remains unclear. One possible factor maybe because of the little we know about COVID-19. Because it is a recently identified disease, COVID-19 has been principally identified by its prominent symptoms such as fever, cough, and dyspnea and not the less common neurological manifestations such as headache, dizziness, and chemosensitive impairment [20]. An analysis of the course of illness has provided evidence that smell and taste impairment are early manifestations of COVID-19, usually appearing in the first 5 days of illness. Ageusia and anosmia were the first symptoms of disease in a number of patients [21]. As recognition of the disease having developed, the reported incidence of chemosensitive impairment in COVID-19 has been considerably higher than in the initial stages, ranging from 19.4 to $88 \%$ [20-23]. In addition, as stated by Bookstaver and collaborators, the clinical symptoms of viral infection are usually nonspecific and sometimes may be mild or symptomless [24]. Therefore, the prevalence of neurological manifestations was very likely underestimated in the early stages of the COVID-19 outbreak [21,23].

CVD is among the most prevalent comorbidities of COVID-19 patients, especially in severe cases. Chen et al. reported that cardiovascular and cerebrovascular diseases were the most prevalent (40/99 [40\%]) chronic underlying conditions [13]. Of the reported 138 hospitalized patients, CVD (7/138, 5.1\%) ranked fifth among the most common comorbidities, while the first to fourth comorbidities were hypertension $(43 / 138,46.4 \%)$, cardiovascular disease $(20 / 138,14.5 \%)$, diabetes $(14 / 138,10.1 \%)$ and cancer $(10 / 138,7.2 \%)$. ICU patients were also more likely to have CVD than non-ICU patients (ICU 6/36 [16.7\%] vs non-ICU $1 / 102$ [1.0\%], $P=0.001$ ) [3]. In addition, CVD and coronary heart disease have been confirmed to be independent risk factors associated with fatal outcome [25]. These observations are understandable as the majority of the reported COVID-19 patients have been elderly (age $\geq 50$ years old, 70\%) [26] who are statistically more likely to have comorbidities and thus more likely to progress into severe cases [27].

\section{Neurotropic evidence of SARS-CoV-2}

On January 3rd, 2020, the first complete genome of SARSCoV-2, the novel coronaviruses that resembles SARS-CoV, was sequenced from a sample of bronchoalveolar lavage 
fluid of a patient from Wuhan [28]. SARS-CoV-2 is a single-stranded RNA coronavirus the genome of which has $89.1 \%$ similarity in its nucleotide sequence to a group of SARS-like coronaviruses. It has been classified as the genus Betacoronavirus, subgenus Sarbecovirus and is the seventh member of the coronavirus family that can infect humans. Of these, four human coronaviruses, NL63, HKU1, 229E, and OC43 typically cause common cold symptoms, while the remaining three are responsible for a number of pandemic infectious diseases, including SARS in 2002 and 2003 (SARS-CoV), MERS in 2012 (MERS-CoV) and COVID-19 (SARS-CoV-2) [5, 29].

Up to now, there is sparse direct evidence of the neurotropism of SARS-CoV-2. However, it has been found that the viral structure as well as the receptor-binding domain of SARS-CoV-2 are similar to that of SARS-CoV. Both SARSCoV-2 and SARS-CoV bind to the ACE2 receptor to access human cells [5]. Therefore, evidence previously found for SARS-CoV may also apply to SARS-CoV-2. A considerable number of studies have provided strong evidence for the neurovirulence of SARS-CoV. Apart from neurological manifestations reported by SARS patients [30], SARS-CoV was detected in samples or specimens of SARS patients. CSF samples of a SARS patient who presented generalized tonic-clonic convulsion tested positive for SARS-CoV, suggesting possible infection of the CNS by SARS-CoV [31]. Jun et al. isolated SARS-CoV from a specimen of brain tissue of a patient with SARS that had presented severe CNS symptoms. Pathological examination of the brain tissue indicated neuronal necrosis and glial cell hyperplasia [32]. Furthermore, SARS viral particles and its genomic sequence were detected in the neurons in the brains of all eight confirmed cases of SARS autopsies. Of these, six confirmed cases presented edema and scattered red degeneration of the neurons [33]. Animal models also provided evidence of SARS-CoV being neurotropic. The results suggested that the brain was the principal target organ for SARS-CoV in the mice transgenic for human ACE2 (hACE2 mice) [34]. SARS-CoV enters the brain mainly through the olfactory bulb and rapidly spreads transneuronally to other related zones of the brain. This widespread neuronal infection and the concomitant neuronal loss, except for lung infection, account for the major cause of death in $h A C E 2$ mice [35]. These findings of neurovirulence in SARS-CoV could provide circumstantial evidence of the neurotropic characteristics of SARS-CoV-2.

In addition, several reports have provided evidences to the neurotropism of SARS-CoV-2. For instance, neurological symptoms, such as headache, dizziness, and impaired consciousness as well as symptoms involving the cranial nerves (hypogeusia, hyposmia, hypopsia, and neuralgia) have been reported in COVID-19 patients [2, 4, 20, 22, 23]. Importantly, the neurological manifestations presented by COVID-19 patients have been nonspecific and difficult to differentiate from encephalopathy induced by systemic viremia occurring outside the CNS [36]. Elderly patients with chronic underlying medical conditions are at increased risk of encephalopathy in the setting of acute infections. In addition, COVID-19 patients, especially severe cases, frequently present severe systemic manifestations such as hypoxia, viremia, cytokine storm and coagulopathy which can induce encephalopathy in addition to the direct effects of SARS-COV-2 [3, 37, 38]. A series of case reports have reported that COVID-19 patients presenting with headache, altered mental status, acute CVD, acute necrotizing hemorrhagic encephalopathy, and acute Guillain-Barré syndrome but without abnormal cerebrospinal fluid (CSF) analysis, which indicates that SARS-CoV-2 does not cross the blood-brain barrier (BBB) and does not cause meningitis or encephalitis [14-18, 39, 40]. Although a direct association between the aforementioned symptoms of encephalopathy and COVID-19 requires further investigation, COVID-19 should be considered first when conducting differential diagnosis during the pandemic because of the probable risk of transmission as a result of missed diagnosis.

Recently, Takeshi et al. reported the first case of meningitis/encephalitis associated with SARS-CoV-2. They detected SARS-CoV-2 RNA in the CSF specimen [19], providing direct evidence of the neuroinvasiveness of SARS-CoV-2. In addition, the pathological findings of brain tissue in COVID19 patients have been reported in the gross anatomy of a patient admitted because of cerebral infarction and diagnosed as having COVID-19 on the 13th day of admission. Only nonspecific brain edema and atrophy without further histopathological observations were found by gross anatomical examination of this patient and without any signs of infection [41]. Thus, detailed neurological examination and attempts to separate SARS-CoV-2 from the neuronal tissue are required to provide direct neurotropic evidence of SARS-CoV-2 [8].

\section{Potential neurotropic mechanisms of SARS-CoV-2}

The underlying neurotropic mechanisms of SARS-CoV-2 have yet to be established. However, the neurotropic mechanisms previously found in SARS-CoV and other viruses may serve as a reference for SARS-CoV-2.

There are essentially two principal routes for viruses to gain entry into the CNS: hematogenous or neuronal retrograde dissemination $[36,42,43]$. In hematogenous entry, a virus can infect endothelial cells of the BBB to gain access or infect leukocytes for dissemination into the CNS [36, $42,43]$. It has been speculated that SARS-CoV infects endothelial cells of the BBB following viremia, allowing 
direct passage across the BBB into the CNS [44]. SARSCoV-2 may also bind to ACE2 expressed in the capillary endothelium of BBB to gain access into the CNS [8]. On the other hand, it has also been found that SARS-CoV can infect monocytes and macrophages to migrate through the BBB [33].

As a second major route of entry to the CNS, some viruses infect neurons in the periphery and use the axonal transport machinery to enter the CNS [36, 42, 43]. This could represent another potential route of entry to the CNS for SARS-CoV-2, that is via the cranial nerve. ACE2 is widely expressed on the epithelial cells of the oral mucosa [45]. Moreover, the olfactory nerve serves as a shortcut for many viruses into the CNS [46]. Olfactory receptor neurons project dendrites into the nasal cavity and extend axons through the cribriform plate into the olfactory bulb of the brain [46]. It has been reported that nasopharyngeal swabs of multiple patients have tested positive [47, 48], and the major route of transmission of SARS-CoV-2 is via the respiratory tract through the nose. Meanwhile, hyposmia and hypogeusia are neurological manifestations reported in some cases $[4,20,22,23]$. Furthermore, it has been found that SARS-CoV enters the brains of $h A C E 2$ mice mainly through the olfactory bulb, resulting in rapid, transneuronal spread to related areas of the brain [35]. This evidence could partly explain the plausible mechanism of cranial nervous system symptoms in COVID-19.

In addition to the direct infection injury of SARS-CoV-2 to the CNS, SARS-CoV-2 may indirectly affect the CNS [10]. In published reports of SARS-CoV-2, a cytokine storm, elevated D-dimer levels, and thrombocytopenia have been reported [38, 49]. Intracranial cytokine storms, which could result in the breakdown of the BBB without direct viral invasion, might be responsible for the development of acute necrotizing encephalopathy or Guillain-Barré syndrome [16, 17]. Coagulopathy observed in COVID-19, together with a cytokine storm, could render patients prone to cerebrovascular events, both thrombotic and hemorrhagic [18].

\section{Conclusions}

Both the structural basis of SARS-CoV-2 and several indirect and direct evidence mentioned above have provided proof to support the theory of neurotropic involvement of SARS-CoV-2. Thus, considerably more attention should be paid to the risk of neurological involvement in patients with COVID-19. We must keep the diagnosis of SARS-CoV-2 infection in mind when patients presented specific or nonspecific neurological symptoms during the pandemic.

Funding Supported by the National Natural Science Foundation of China (No. 81974279).

\section{Compliance with ethical standards}

Conflicts of interest The authors declare that they have no conflict of interest.

\section{References}

1. Huang C, Wang Y, Li X, Ren L, Zhao J, Hu Y, Zhang L, Fan G, Xu J, Gu X, Cheng Z, Yu T, Xia J, Wei Y, Wu W, Xie X, Yin W, Li H, Liu M, Xiao Y, Gao H, Guo L, Xie J, Wang G, Jiang R, Gao Z, Jin Q, Wang J, Cao B (2020) Clinical features of patients infected with 2019 novel coronavirus in Wuhan, China. Lancet 395(10223):497-506. https://doi.org/10.1016/s0140 $-6736(20) 30183-5$

2. Guan WJ, Ni ZY, Hu Y, Liang WH, Ou CQ, He JX, Liu L, Shan H, Lei CL, Hui DSC, Du B, Li LJ, Zeng G, Yuen KY, Chen RC, Tang CL, Wang T, Chen PY, Xiang J, Li SY, Wang JL, Liang ZJ, Peng YX, Wei L, Liu Y, Hu YH, Peng P, Wang JM, Liu JY, Chen Z, Li G, Zheng ZJ, Qiu SQ, Luo J, Ye CJ, Zhu SY, Zhong NS, China Medical Treatment Expert Group for C (2020) Clinical characteristics of Coronavirus disease 2019 in China. N Engl J Med. https://doi.org/10.1056/NEJMoa2002032

3. Wang D, Hu B, Hu C, Zhu F, Liu X, Zhang J, Wang B, Xiang H, Cheng Z, Xiong Y, Zhao Y, Li Y, Wang X, Peng Z (2020) Clinical characteristics of 138 hospitalized patients with 2019 novel Coronavirus-infected pneumonia in Wuhan, China. JAMA 323(11):1061. https://doi.org/10.1001/jama.2020.1585

4. Mao L, Jin H, Wang M, Hu Y, Chen S, He Q, Chang J, Hong C, Zhou Y, Wang D, Miao X, Li Y, Hu B (2020) Neurologic manifestations of hospitalized patients with Coronavirus disease 2019 in Wuhan, China. JAMA Neurol. https://doi.org/10.1001/jaman eurol.2020.1127

5. Lu R, Zhao X, Li J, Niu P, Yang B, Wu H, Wang W, Song H, Huang B, Zhu N, Bi Y, Ma X, Zhan F, Wang L, Hu T, Zhou H, Hu Z, Zhou W, Zhao L, Chen J, Meng Y, Wang J, Lin Y, Yuan J, Xie Z, Ma J, Liu WJ, Wang D, Xu W, Holmes EC, Gao GF, Wu G, Chen W, Shi W, Tan W (2020) Genomic characterisation and epidemiology of 2019 novel coronavirus: implications for virus origins and receptor binding. Lancet 395(10224):565-574. https ://doi.org/10.1016/S0140-6736(20)30251-8

6. Zou X, Chen K, Zou J, Han P, Hao J, Han Z (2020) Single-cell RNA-seq data analysis on the receptor ACE2 expression reveals the potential risk of different human organs vulnerable to 2019nCoV infection. Front Med. https://doi.org/10.1007/s1168 4-020-0754-0

7. Alenina N, Bader M (2019) ACE2 in brain physiology and pathophysiology: evidence from transgenic animal models. Neurochem Res 44(6):1323-1329. https://doi.org/10.1007/s11064-018-2679-4

8. Baig AM, Khaleeq A, Ali U, Syeda H (2020) Evidence of the COVID-19 virus targeting the CNS: tissue distribution, host-virus interaction, and proposed neurotropic mechanisms. ACS Chem Neurosci. https://doi.org/10.1021/acschemneuro.0c00122

9. Li YC, Bai WZ, Hashikawa T (2020) The neuroinvasive potential of SARS-CoV2 may play a role in the respiratory failure of COVID-19 patients. J Med Virol. https://doi.org/10.1002/ jmv. 25728

10. Wu Y, Xu X, Chen Z, Duan J, Hashimoto K, Yang L, Liu C, Yang C (2020) Nervous system involvement after infection with COVID-19 and other coronaviruses. Brain Behav Immun. https ://doi.org/10.1016/j.bbi.2020.03.031

11. Rodriguez-Morales AJ, Cardona-Ospina JA, Gutiérrez-Ocampo E, Villamizar-Peña R, Holguin-Rivera Y, Escalera-Antezana JP, Alvarado-Arnez LE, Bonilla-Aldana DK, Franco-Paredes 
C, Henao-Martinez AF, Paniz-Mondolfi A, Lagos-Grisales GJ, Ramírez-Vallejo E, Suárez JA, Zambrano LI, Villamil-Gómez WE, Balbin-Ramon GJ, Rabaan AA, Harapan H, Dhama K, Nishiura H, Kataoka H, Ahmad T, Sah R (2020) Clinical, laboratory and imaging features of COVID-19: a systematic review and meta-analysis. Travel Med Infect Dis. https://doi.org/10.1016/j. tmaid.2020.101623

12. Wang Z, Yang B, Li Q, Wen L, Zhang R (2020) Clinical features of 69 cases with Coronavirus disease 2019 in Wuhan, China. Clin Infect Dis. https://doi.org/10.1093/cid/ciaa272

13. Chen N, Zhou M, Dong X, Qu J, Gong F, Han Y, Qiu Y, Wang J, Liu Y, Wei Y, Xia Ja YuT, Zhang X, Zhang L (2020) Epidemiological and clinical characteristics of 99 cases of 2019 novel coronavirus pneumonia in Wuhan, China: a descriptive study. Lancet 395(10223):507-513. https://doi.org/10.1016/s0140 $-6736(20) 30211-7$

14. Oxley TJ, Mocco J, Majidi S, Kellner CP, Shoirah H, Singh IP, De Leacy RA, Shigematsu T, Ladner TR, Yaeger KA, Skliut M, Weinberger J, Dangayach NS, Bederson JB, Tuhrim S, Fifi JT (2020) Large-vessel stroke as a presenting feature of Covid-19 in the young. N Engl J Med. https://doi.org/10.1056/NEJMc20097 87

15. Li Y, Wang M, Zhou Y, Chang J, Xian Y, Mao L, Hong C, Chen S, Wang Y, Wang H, Li M, Jin H, Hu B (2020) Acute cerebrovascular disease following COVID-19: a single center, retrospective, observational study. https://ssrn.com/abstract $=3550025$. Accessed 13 Mar 2020

16. Poyiadji N, Shahin G, Noujaim D, Stone M, Patel S, Griffith B (2020) COVID-19-associated acute hemorrhagic necrotizing encephalopathy: CT and MRI features. Radiology. https://doi. org/10.1148/radiol.2020201187

17. Zhao H, Shen D, Zhou H, Liu J, Chen S (2020) Guillain-Barre syndrome associated with SARS-CoV-2 infection: causality or coincidence? Lancet Neurol 19(5):383-384. https://doi. org/10.1016/S1474-4422(20)30109-5

18. Al Saiegh F, Ghosh R, Leibold A, Avery MB, Schmidt RF, Theofanis T, Mouchtouris N, Philipp L, Peiper SC, Wang ZX, Rincon F, Tjoumakaris SI, Jabbour P, Rosenwasser RH, Gooch MR (2020) Status of SARS-CoV-2 in cerebrospinal fluid of patients with COVID-19 and stroke. J Neurol Neurosurg Psychiatry. https ://doi.org/10.1136/jnnp-2020-323522

19. Moriguchi T, Harii N, Goto J, Harada D, Sugawara H, Takamino J, Ueno M, Sakata H, Kondo K, Myose N, Nakao A, Takeda M, Haro H, Inoue O, Suzuki-Inoue K, Kubokawa K, Ogihara S, Sasaki T, Kinouchi H, Kojin H, Ito M, Onishi H, Shimizu T, Sasaki Y, Enomoto N, Ishihara H, Furuya S, Yamamoto T, Shimada S (2020) A first case of meningitis/encephalitis associated with SARS-Coronavirus-2. Int J Infect Dis. https://doi. org/10.1016/j.ijid.2020.03.062

20. Giacomelli A, Pezzati L, Conti F, Bernacchia D, Siano M, Oreni L, Rusconi S, Gervasoni C, Ridolfo AL, Rizzardini G, Antinori S, Galli M (2020) Self-reported olfactory and taste disorders in SARS-CoV-2 patients: a cross-sectional study. Clin Infect Dis. https://doi.org/10.1093/cid/ciaa330

21. Vaira LA, Deiana G, Fois AG, Pirina P, Madeddu G, De Vito A, Babudieri S, Petrocelli M, Serra A, Bussu F, Ligas E, Salzano G, De Riu G (2020) Objective evaluation of anosmia and ageusia in COVID-19 patients: single-center experience on 72 cases. Head Neck. https://doi.org/10.1002/hed.26204

22. Lechien JR, Chiesa-Estomba CM, De Siati DR, Horoi M, Le Bon SD, Rodriguez A, Dequanter D, Blecic S, El Afia F, Distinguin L, Chekkoury-Idrissi Y, Hans S, Delgado IL, Calvo-Henriquez C, Lavigne P, Falanga C, Barillari MR, Cammaroto G, Khalife M, Leich P, Souchay C, Rossi C, Journe F, Hsieh J, Edjlali M, Carlier R, Ris L, Lovato A, De Filippis C, Coppee F, Fakhry N, Ayad T, Saussez S (2020) Olfactory and gustatory dysfunctions as a clinical presentation of mild-to-moderate forms of the coronavirus disease (COVID-19): a multicenter European study. Eur Arch Oto-Rhino-Laryngol. https://doi.org/10.1007/s00405-020-05965 $-1$

23. Vaira LA, Salzano G, Deiana G, De Riu G (2020) Anosmia and ageusia: common findings in COVID-19 patients. Laryngoscope. https://doi.org/10.1002/lary.28692

24. Bookstaver PB, Mohorn PL, Shah A, Tesh LD, Quidley AM, Kothari R, Bland CM, Weissman S (2017) Management of viral central nervous system infections: a primer for clinicians. J Cent Nerv Syst Dis 9:1179573517703342. https://doi. org/10.1177/1179573517703342

25. Chen R, Liang W, Jiang M, Guan W, Zhan C, Wang T, Tang C, Sang L, Liu J, Ni Z, Hu Y, Liu L, Shan H, Lei C, Peng Y, Wei L, Liu Y, Hu Y, Peng P, Wang J, Liu J, Chen Z, Li G, Zheng Z, Qiu S, Luo J, Ye C, Zhu S, Liu X, Cheng L, Ye F, Zheng J, Zhang N, Li Y, He J, Li S, Zhong N (2020) Risk factors of fatal outcome in hospitalized subjects with coronavirus disease 2019 from a nationwide analysis in China. Chest. https://doi.org/10.1016/j. chest.2020.04.010

26. Zhang JJ, Dong X, Cao YY, Yuan YD, Yang YB, Yan YQ, Akdis CA, Gao YD (2020) Clinical characteristics of 140 patients infected with SARS-CoV-2 in Wuhan, China. Allergy. https:// doi.org/10.1111/all.14238

27. Jordan RE, Adab P, Cheng KK (2020) Covid-19: risk factors for severe disease and death. BMJ 368:m1198. https://doi. org/10.1136/bmj.m1198

28. Tan W, Zhao X, Ma X, Wang W, Niu P, Xu W, Gao G, Wu G (2020) A novel coronavirus genome identified in a cluster of pneumonia cases-Wuhan, China 2019-2020. China CDC Wkly 2:61-62

29. Zhu N, Zhang D, Wang W, Li X, Yang B, Song J, Zhao X, Huang B, Shi W, Lu R, Niu P, Zhan F, Ma X, Wang D, Xu W, Wu G, Gao GF, Tan W (2020) A novel Coronavirus from patients with pneumonia in China, 2019. N Engl J Med 382(8):727-733. https ://doi.org/10.1056/NEJMoa2001017

30. Tsai LK, Hsieh ST, Chang YC (2005) Neurological manifestations in severe acute respiratory syndrome. Acta Neurol Taiwan 14(3):113-119

31. Lau KK, Yu WC, Chu CM, Lau ST, Sheng B, Yuen KY (2004) Possible central nervous system infection by SARS coronavirus. Emerg Infect Dis 10(2):342-344. https://doi.org/10.3201/eid10 02.030638

32. Xu J, Zhong S, Liu J, Li L, Li Y, Wu X, Li Z, Deng P, Zhang J, Zhong N, Ding Y, Jiang Y (2005) Detection of severe acute respiratory syndrome coronavirus in the brain: potential role of the chemokine mig in pathogenesis. Clin Infect Dis 41(8):1089-1096. https://doi.org/10.1086/444461

33. Gu J, Gong E, Zhang B, Zheng J, Gao Z, Zhong Y, Zou W, Zhan J, Wang S, Xie Z, Zhuang H, Wu B, Zhong H, Shao H, Fang W, Gao D, Pei F, Li X, He Z, Xu D, Shi X, Anderson VM, Leong AS (2005) Multiple organ infection and the pathogenesis of SARS. J Exp Med 202(3):415-424. https://doi.org/10.1084/jem.20050828

34. McCray PB Jr, Pewe L, Wohlford-Lenane C, Hickey M, Manzel L, Shi L, Netland J, Jia HP, Halabi C, Sigmund CD, Meyerholz DK, Kirby P, Look DC, Perlman S (2007) Lethal infection of K18-hACE2 mice infected with severe acute respiratory syndrome coronavirus. J Virol 81(2):813-821. https://doi.org/10.1128/ JVI.02012-06

35. Netland J, Meyerholz DK, Moore S, Cassell M, Perlman S (2008) Severe acute respiratory syndrome coronavirus infection causes neuronal death in the absence of encephalitis in mice transgenic for human ACE2. J Virol 82(15):7264-7275. https://doi. org/10.1128/JVI.00737-08

36. Desforges M, Le Coupanec A, Dubeau P, Bourgouin A, Lajoie L, Dube M, Talbot PJ (2019) Human Coronaviruses and other 
respiratory viruses: underestimated opportunistic pathogens of the central nervous system? Viruses. https://doi.org/10.3390/v1201 0014

37. Zhou F, Yu T, Du R, Fan G, Liu Y, Liu Z, Xiang J, Wang Y, Song B, Gu X, Guan L, Wei Y, Li H, Wu X, Xu J, Tu S, Zhang Y, Chen H, Cao B (2020) Clinical course and risk factors for mortality of adult inpatients with COVID-19 in Wuhan, China: a retrospective cohort study. Lancet 395(10229):1054-1062. https ://doi.org/10.1016/s0140-6736(20)30566-3

38. Mehta P, McAuley DF, Brown M, Sanchez E, Tattersall RS, Manson JJ, H1h Across Speciality Collaboration UK (2020) COVID19: consider cytokine storm syndromes and immunosuppression. Lancet 395(10229):1033-1034. https://doi.org/10.1016/S0140 $-6736(20) 30628-0$

39. Filatov A, Sharma P, Hindi F, Espinosa PS (2020) Neurological complications of Coronavirus disease (COVID-19): encephalopathy. Cureus 12(3):e7352. https://doi.org/10.7759/cureus.7352

40. Yin R, Feng W, Wang T, Chen G, Wu T, Chen D, Lv T, Xiang D (2020) Concomitant neurological symptoms observed in a patient diagnosed with coronavirus disease 2019. J Med Virol. https://doi. org/10.1002/jmv.25888

41. Qian L, Rongshuai W, Guoqiang Q, Yunyun W, Pan L, Yingzhi Z, Geng F, Liang R, Yiwu Z, Liang L (2020) A report on the general observation of the necropsy of a newly developed coronavirus pneumonia. Fa Yi Xue Za Zhi 36(1):21-23

42. Swanson PA 2nd, McGavern DB (2015) Viral diseases of the central nervous system. Curr Opin Virol 11:44-54. https://doi. org/10.1016/j.coviro.2014.12.009

43. Desforges M, Le Coupanec A, Stodola JK, Meessen-Pinard M, Talbot PJ (2014) Human coronaviruses: viral and cellular factors involved in neuroinvasiveness and neuropathogenesis. Virus Res 194:145-158. https://doi.org/10.1016/j.virusres.2014.09.011

44. Guo Y, Korteweg C, McNutt MA, Gu J (2008) Pathogenetic mechanisms of severe acute respiratory syndrome. Virus Res 133(1):4-12. https://doi.org/10.1016/j.virusres.2007.01.022

45. Xu H, Zhong L, Deng J, Peng J, Dan H, Zeng X, Li T, Chen Q (2020) High expression of ACE2 receptor of 2019-nCoV on the epithelial cells of oral mucosa. Int J Oral Sci 12(1):8. https://doi. org/10.1038/s41368-020-0074-x

46. van Riel D, Verdijk R, Kuiken T (2015) The olfactory nerve: a shortcut for influenza and other viral diseases into the central nervous system. J Pathol 235(2):277-287. https://doi.org/10.1002/ path. 4461

47. Wu P, Duan F, Luo C, Liu Q, Qu X, Liang L, Wu K (2020) Characteristics of ocular findings of patients with Coronavirus disease 2019 (COVID-19) in Hubei Province, China. JAMA Ophthalmol. https://doi.org/10.1001/jamaophthalmol.2020.1291

48. Wu Z, McGoogan JM (2020) Characteristics of and important lessons from the Coronavirus disease 2019 (COVID-19) outbreak in China: summary of a report of 72314 cases from the Chinese center for disease control and prevention. JAMA. https://doi. org/10.1001/jama.2020.2648

49. Zhang Y, Xiao M, Zhang S, Xia P, Cao W, Jiang W, Chen H, Ding X, Zhao H, Zhang H, Wang C, Zhao J, Sun X, Tian R, Wu W, Wu D, Ma J, Chen Y, Zhang D, Xie J, Yan X, Zhou X, Liu Z, Wang J, Du B, Qin Y, Gao P, Qin X, Xu Y, Zhang W, Li T, Zhang F, Zhao Y, Li Y, Zhang S (2020) Coagulopathy and antiphospholipid antibodies in patients with Covid-19. N Engl J Med 382(17):e38. https://doi.org/10.1056/NEJMc2007575 